\title{
Tort Claims and the Bankrupt Corporation
}

When a corporation goes bankrupt, termination of operations accompanies liquidation; hence participation in the bankruptcy proceedings is almost always the last opportunity for those holding claims against the corporation to collect. ${ }^{1}$ As a general rule, commercial creditors are allowed to prove their claims in bankruptcy proceedings.? The present Bankruptcy Act, however, bars many tort victims from participating in the final distribution of a corporation's assets. ${ }^{3}$ The following hypothetical fact situation illustrates the most important inequities in the present treatment of tort claims against corporate bankrupts.

Hypothetical Lumber, Inc., has assets consisting largely of virgin timber land. During October 1967, Hypothetical mistakenly fells trees belonging to a local businessman and, in its company newspaper, defames another local citizen. The two victims institute law suits in trespass and libel respectively, and by late August 1968 both suits seem to be nearing judgment or settlement. On August 28, 1968, Hypothetical's negligence causes a forest fire which consumes most of the firm's timber resources. The fire also destroys a large stand of timber owned by ABC Corporation but managed by Hypothetical under an agreement providing that Hypothetical should protect the timber from all damage. Several persons, including an elderly lady who owes Hypothetical $\$ 500$ for firewood purchased, are severely burned in the fire. Only one of the injured files suit before August 31st. On that date, Hypothetical's management, aware that the destruction of its timber resources has rendered the firm hopelessly insolvent, files a voluntary petition in bankruptcy.

1. An adjudication of bankruptcy does not automatically terminate corporate cxistence. In re Russell Wheel \& Foundry Co., 222 F. 569 (E.D. Mich. 1915); Morley v. Thayer, 3 F. 737 (C.C.D. Mass. 1880); see Chemical Bank v. Hartford Deposit Co., 161 U.S. 1 (1895). Howerer, the bankruptcy process distributes all of a corporation's assets. Hence, claimants against the corporation who cannot participate in bankruptcy pro. ceedings are unable to reach any assets to satisfy judgments which tcchnically they could still obtain outside bankruptcy. Members of the House of Representatives have recognized the irrelevance of nondischargeability to the creditors of a corporation: "Although a corporate bankrupt is theoretically not discharged, the corporation normally ceases to exist upon bankruptcy and unsatisfied tax claims as well as other unsatisfied claims are without further recourse ..." H.R. REP. No. 687, 89th Cong., Ist Sess. 2 (1965).

2. Creditors with claims based on open account or on express or implied contracts may prove their claims. Bankruptcy Act $\$ 63 a(4), 11$ U.S.C. $\S 103 a(4)$ (1964).

3. This Note is concerned with the treatment of tort claims against corporations only in straight bankruptcy proceedings under Sections $1-72$ of the Bankrupte; Act, 11 US.C. $\S \S 1-112$ (1964). 
Although insolvent, ${ }^{4}$ Hypothetical has sufficient assets to pay a bankruptcy dividend of fifty cents per claim dollar to its unsecured creditors, including all of the described tort claimants. Under current bankruptcy law, however, certain of the tort victims have claims that are not provable in bankruptcy; these victims are not permitted to share in the distribution of the bankrupt's assets. Thus, even though participation in the bankruptcy process is the tort victims' only chance for recovery, the damage claims of the libel and trespass ${ }^{5}$ victims and the claims of all those injured in the fire who have not instituted suits prior to bankruptcy will not be honored. Only $A B C$ (suing on a contract theory) and the one injured person who begins his suit before August 31st have provable claims. Not only is the elderly lady unable to collect for her injuries, but she also remains liable for her clebt to Hypothetical, the proceeds from which will be divided among those creditors holding provable claims.

These curious results come about because the Bankruptcy Act makes only certain types of tort claims provable. All tort claims reduced to a fixed liability at the date the bankruptcy petition is filed, as evidenced by a written settlement agreement or by a judgment, are provable. ${ }^{0}$ Likewise, any workmen's compensation award for injury or death from injury is provable, ${ }^{7}$ as is any claim based on a tort action for negligence that is pending at the time the bankruptcy petition is filed. ${ }^{8}$ Moreover, if a claim based on tort can also be regarded as based on breach of an express or implied contract, it may be proved as a contract claim. ${ }^{0}$ And if the bankrupt has been unjustly enriched as a result of its tortious conduct, a claim based on quasi-contract for benefit received may

4. A person shall be deemed insolvent within the provision of this Act whenever the aggregate of his property exclusive of any property which he may have conveycd, transferred, concealed, removed, or permitted to be concealed or removed, with intent to defraud, hinder, or delay his creditors, shall not at a fair valuation be sufficient, in amount to pay his debts.

11 U.S.C. § $1(19)(1964)$.

5. The trespass victim will, however, be able to prove his claim to the extent Hypothetical was unjustly enriched by cutting the trees. See text \& note 10 infra.

6. Bankruptcy Act $\S 63 \mathrm{a}(1), 11$ U.S.C. $\$ 103 \mathrm{a}(1)(1964)$.

7. Bankruptcy Act $\S 63 \mathrm{a}(6), 11$ U.S.C. $\$ 103 \mathrm{a}(6)(1964)$.

8. Bankruptcy Act $\S 63 a(7), 11$ U.S.C. $\S 103 a(7)(1964)$.

9. Thus an injured paying passenger may base his claim on a breach of the contractual duty of safe carriage. In re Great Orme Tramways Co., 50 T.L.R. 450 (Ch. 1934). A person injured by her hairdresser may prove her claim or a breach of the duty to do a reasonably careful job. Dixon v. Kantor, 165 Misc. 315, 299 N.Y.S. 507 (N.X. City Ct. 1937). Or a claim for damaged goods, if based on a breach of warranty, may be proved. F.L. Grant Shoe Co. v. W.M. Laird Co., 212 U.S. 445 (1909). Gencrally, if the claim arose during a contractual relationship between the bankrupt and the claimant, it is provable. However, it is not sufficient to establish merely that the claintant was an employee of the bankrupt. In re Crescent Lumber Co., 154 F. 724 (S.D. Ala. 1907). 
sometimes be proved against the bankrupt's estate. ${ }^{10}$ But those claims not specifically made provable by the Bankruptcy Act may not be proved at all, ${ }^{11}$ and may not even be asserted as a setoff or counterclaim against a suit brought by the corporation's trustee in bankruptcy. ${ }^{12}$ The result is that most tort claims

will be denied participation in the bankruptcy procedure. Others will be received only to be cast out; only a few will run the course of bankruptcy proceeding and be subject to its asset gathering and distributing processes. ${ }^{13}$

When the Bankruptcy Act denies recovery in bankruptcy proceedings for tort claims against a corporation, the tort claimant may be able to obtain compensation from the corporation's insurers, ${ }^{14}$ from the corporation's employee who actually committed the tort, or from the corporation's shareholders. But unfortunately for the average tort claimant, these roads to recovery are not often open.

A bankrupt corporation, which normally will have been poorly managed and inadequately financed, will probably not have carried sufficient insurance for tort liability. Some corporations heading toward bankruptcy carry no liability insurance whatsoever, while others insure only to the inadequate extent required by state law. ${ }^{15}$

10. Schall v. Camors, 251 U.S. 239 (1920); Crawford v. Burke, 195 U.S. 176 (1904); United States v. Duggan, 210 F.2d 926 (8th Cir. 1954); Clarke v. Rogers, 183 F. 518 (lst Cir. 1910), aff'd, 228 U.S. 534 (1913). Such claims are provable only to the cxtent that the bankrupt tortfeasor was unjustly enriched, which may be considerably less than the total damages to the victim. In addition, a claim for patent infringement is not provable even to the extent of unjust enrichment. Goldsmith v. Overseas Scientific Corp., 188 F. Supp. 530 (S.D.N.Y. 1960); In re Paramount Publix Corp., 8 F. Supp. 614 (S.D.N.Y. 1934). Contra, Schiff v. Hammond Clock, 69 F.2d 742 (7th Cir. 1934), rocaled as moot, 293 U.S. 529 (1934).

11. Schall v. Camors, 251 U.S. 239 (1920); Goldsmith v. Orcrseas Scientific Corp., 188 F. Supp. 530 (S.D.N.Y. 1960); In re Shawsheen Diary, Inc, 47 F. Supp. 494 (D. Mass. 1942).

12. Bankruptcy Act $\S 68,11$ U.S.C. $\$ 108$ (1964).

13. Joslin, Torts \& Bankruptg-A Synthesis, 1 B.C. IND. \&. Cos. L. REv. 185. 195 (1960).

14. Although the bankrupt corporation's estate is not liable for non-provable claims, the obligations of the insurers of a corporation are not ordinarily terminated by bankruptcy. However, some insurance policies stipulate that the insurer is liable to reimburse the insured only for damage payments which the insured has actually made. Thus, since a bankrupt corporation does not pay any non-provable claims, the insurer is not obligated to compensate the tort victim. Many states have wiscly prohibited the issuance of this type of insurance, but such policies still cxist and occasionally prevent a tort victim from recovery against the insurer. For a discussion of such insurance and citation of state statutes forbidding it, see TV. VANCE, INSURANCE $\S 135$ (3d cd. 1951).

15. A typical state requirement is that corporations insure against motor velicle tort liability. See, e.g., Motor Vehicle Financial Security Act \$ 3, N.Y. VEnICLE \&. TrAfric LAw \& 312 (McKinney 1960). High deductibility provisions (the insurer is not liable for damages which are less than a certain amount) and low maximum liability limits (the insurer is not liable for damages in excess of a set amount) are other limitations found in the insurance programs of corporations which are likely to go bankrupt. For an cxam- 
Moreover, even an insured corporation is unlikely to insure itself against those tort claims which are least likely to be provable-such as patent and copyright infringement and willful torts.

The tort victim holding a non-provable claim may, of course, sue the corporate employee who is personally liable for the tort. The basic weakness of this remedy is that most such employees are uninsured and judgment proof. For many modern corporate torts, moreover, although it is easy to place liability on a corporation, it is nearly impossible to identify the specific employee responsible. ${ }^{16}$ Finally, the courts will sometimes allow creditors to "pierce the corporate veil" and recover from stockholders of a bankrupt corporation directly. ${ }^{17}$ Such suits, however, are usually founded on a reliance element lacking in tort cases. ${ }^{18}$

The exclusion of many tort claims from a corporation's bankruptcy proceedings coupled with the unavailability or inadequacy of claims against the corporation's insurer, employees, or stockholders results in a denial of compensation to many victims of torts committed by corporations that later become bankrupt. ${ }^{19}$ Of course the non-provability of many tort claims makes a difference only when the bankrupt corporation has assets sufficient to pay some amount on general claims after paying the claims given priority by the Bankruptcy Act. ${ }^{20}$ In such cases, the present exclusion of tort claims allows those holding provable claims to receive more per dollar of claim than they would if the excluded tort claims were made provable. Since most of their claims are contractual, commercial creditors would favor continuing the present

ple of seriously inadequate statutory maximum liability limits, sce Mull v. Colt Co., SI F.R.D. 154 (S.D.N.Y. 1962).

16. For instance, if a man is hit by a falling piece of steel while he is walking below a high-rise construction project, it may well be impossible to determine which construction worker caused the object to fall, even allowing for the extension of res ipsa loquitor found in Ybarra v. Spangard, 25 Cal. 2d 486, 154 P.2d 687 (1944). Nevertheless, it is clear that, under most circumstances, the construction corporation would be liable for damages.

17. Mull v. Colt Co., 31 F.R.D. 154 (S.D.N.Y. 1962). A recent decision of the Callifornia Supreme Court has allowed tort victims to recover from the primary commercial lender of a corporation whose tortious activities were known or should have been known by the lender. Connor v. Great Western Sav. \& Loan Ass'n, 69 Cal. 2d 887, 73 Cal. Rptr. 869 447 P.2d 609 (1968).

18. See, e.g., Weisser v. Mursam Shoe Corp., 127 F.2d 344 (2d Cir. 1942). For a dis. cussion of the current limits of the "veil-piercing" doctrine and a proposal for sub. stantially expanding it, see Note, Should Shareholders Be Personally Liable for the Torts of Their Corporations, 76 YALE L.J. 1190 (1967).

19. Torts for which a corporation's estate is liable which occur after a bankruptcy petition is filed give rise to claims which are entitled to first priority as administrative expenses. Bankruptcy Act \& 64a, 11 U.S.C. \$ 104a (1964); see Reading Co. v. Brown, 891 U.S. 471 (1968).

20. Bankruptcy Act \& 64a, 11 U.S.C. \& $104 a$ (1964). 
treatment of tort claims. On the other hand, commercial creditorsunlike the victims of corporate torts-often enter voluntarily into credit relations with financially weak corporations. ${ }^{21}$ Solid justification is necessary for favoring commercial creditors over tort claimants.

One justification offered for excluding many tort claims from bankruptcy proceedings is that historically bankruptcy has been exclusively a commercial device. ${ }^{22}$ But American bankruptcy laws have never been confined to commercial claims; they have long permitted the assertion of tort claims reduced to judgment prior to bankruptcy. ${ }^{23}$ More importantly, the fact that bankruptcy law has traditionally favored commercial debts does not justify the present exclusion of tort claims against bankrupt corporations. Most modern observers recognize that such claims should be viewed as costs of business operation differing in no important respect from debts for supplies or labor used in the business. ${ }^{24}$

A second frequently asserted justification is that tort liability is personal and quasi-criminal and therefore only the tort feasor, and not his creditors, should be subjected to the punishment of paying tort damages. ${ }^{25}$ When the tort feasor is a corporation this argument implies not going beyond the stockholder's equity to satisfy tort claims. ${ }^{20}$ But this justification for denying many tort claimants the right to share with commercial creditors in the assets of the bankrupt corporation is not consistent with modern tort theory, which considers the compensation of victims a primary function of tort liability. ${ }^{27}$ Moreover, non-

21. For example suppose a corporation owning taxi cabs negligently injures a passenger and a pedestrian in the same accident. While the passenger an prove his claim on the basis of implied contract, the pedestrian can prove his only if he has filed a negligence suit before bankruptcy. A cynic might observe that the person who enters a taxi (at least in New York City) should be treated less favorably than the pedestrian, as he has assumed the risk. Such an observation is by no means facetious in many business situations. When tortious conduct is also a breach of a contractual duty, the injured party can often foresee the possibility of injury and take the opportunity to make certain that the risk is insured.

22. Schall v. Camors, 251 U.S. 239 (1920).

23. Glenn, Basic Considerations in Tort Claims in Bankruptcy and Reorganization, I8 N.Y.U.L.Q. REv. 367, 369 (1941). As Glenn suggests, the provability of tort judgments was justified by regarding the judgments, through the fiction of "contract on record," as contractual debts.

24. See, e.g., Calabresi, Some Thoughts on Risk Distribution and the Law of Torts, 70 YALE L.J. 499 (1961); Morris, Enterprise Liability and the Actuarial Proces-The Insignificance of Foresight, 70 YALE L.J. 554 (1961).

25. G. GLENN, Liqumation \& 466 (1935).

26. Of course, since assets less liabilities equal shareholder equity, by definition there can be no shareholder's equity when a corporation is bankrupt.

27. See Calabresi, supra note 24; Morris, supra note 24; Glenn observes that while at common law tort ciaims generally could not be proved against a decedent's estate, many jurisdictions have, by statute, made these torts provable. He argues that the law should regard proving torts against a corporation as analogous to proving torts against 
fault tort liability, which represents society's apportionment of the risks of particular activities, should not be regarded as punitive in any sense. Finally, the argument that tort claims are punishment from which the bankrupt's creditors ought to be shielded seems to be implicitly rejected by the present Act itself in that some fault-based tort claims are provable in circumstances in which non-fault tort claims could not be proved. ${ }^{28}$

A third justification sometimes offered is that because tort claims are contingent in validity and amount, proving them would delay the bankruptcy process. ${ }^{29}$ The short answer to this argument is that those tort claims which would cause undue delay should be excludable, not because they are tort claims, but because they will take too long to process. Section $57 \mathrm{~d}$ of the present $\mathrm{Act}^{30}$ independently authorizes a bankruptcy court to disallow any claim if its liquidation would unduly delay the administration of the debtor's estate. There is therefore no need to make whole classes of tort claims non-provable because of the danger that particular claims might cause undue delay. ${ }^{31}$

In sum, there is no adequate justification for the present exclusion of many tort claims against bankrupt corporations. Perhaps this treat-

a decedent's estate because both situations present the last chance for a tort victim to receive compensation for his injuries. G. GLEN, LIQuidation \& 490 (1935). This analogy seems persuasive: the change in the law of decedents estates is also cogent evidence of the shift in the function of tort law from penal to compensatory objectives. The shift, as we have seen, undermines one of the justifications for excluding tort claims from bankruptcy. See p. 479 supra.

28. Non-fault torts must be reduced to judgment at the date the bankruptcy petition is filed in order to be proved. Bankruptcy Act $\S 63 a(1), 11$ U.S.C. $\S 103 a(1)$ (1961). In contrast, negligent torts are provable if a suit has been instituted and is pending when the petition is filed. Bankruptcy Act $\$ 63 \mathrm{a}(7), 11$ U.S.C. $\$ 103 \mathrm{a}(7)(1964)$.

29. In re Shawsheen Dairy, Inc., 47 F. Supp. 494 (D. Mass. 1942). Judge Wyzanski summarizes the various justifications commonly offered in support of the exclusion of tort claims. Id. at 498 .

30. 11 U.S.C. \& $93 \mathrm{~d}$ (1964).

31. The operation of the present tort claim exclusion on counterclaims by the corporation's debtors provides a good illustration that these rules of provability have no relation to whether a particular claim or even a group of claims may be casily liquidated. Bankruptcy Act \& 68a, Il U.S.C. § 108 a (1964), dictates that in the casc of mutual debts between the estate of the bankrupt and a creditor, one debt should be set off against the other, and only the net balance shall be allowed the claimant or be paid to the bankrupt. Section 68b, 11 U.S.C. $\S 108 \mathrm{~b}$ (1964), however, states that claims that are not provable are not permissible setofts. See New York Credit Mcn's Adjustment Bureau, Inc. v. Bruno-New York, Inc., 120 F. Supp. 495 (S.D.N.Y. 1954). But a setoff or counterclaim arises only when the bankruptcy trustec has already filed a law suit and thereby asserted a claim which itself will take time to liquidatc. Unless and until the trustee completes that lawsuit, the setoff has no effect; so there is no need to exclude the setoff on the grounds that the administration of the estate will be unduly hindered. There may be situations in which allowing a sctoff or counterclaim would unduly delay the bankruptcy process-for example, if the trustce sucs to recover a simple debt and the defendant counterclaims with a highly speculative and complex patent infringement suit. Nevertheless these situations could best be judged by the more precise test of Section $57 d$. 
ment of tort claims has resulted in large part because actual and potential tort claimants have had little collective influence in the development of the Bankruptcy Act. ${ }^{32}$ The uneven play of interest group pressures has given us a Bankruptcy Act that unreasonably discriminates between claims of substantially equivalent merit. ${ }^{33}$

In the case of the bankruptcy of natural persons, there might be some rationality in the present system requiring some tort claimants to participate with general creditors in the bankrupt's estate and requiring others to assert their claims only against those assets accumulated by the bankrupt after bankruptcy. ${ }^{3 i}$ In the case of a bankrupt corporation, however, to permit only some tort claims to be proved makes no sense at all. Valid tort claims are as much costs of operating a business as are amounts due for goods received, and yet those tort claimants who are not allowed to prove their claims in the bankruptcy proceedings will never be able to look to the corporation for compensation. ${ }^{35}$

The conclusion that all pre-bankruptcy torts ought to be provable against a corporate bankrupt has already been accepted in those chapters of the Bankruptcy Act providing for the rehabilitation rather than liquidation of insolvent corporations. ${ }^{30}$ It would appear desirable to

32. The Bankruptcy Act is very much a product of interest group politics. As Justice Pitney indicated: "It [the Act] was the result of a long period of agitation, participatcd in by commercial conventions, boards of trade, chambers of commerce, and other commercial bodies." Schall v. Camors, 251 U.S. 239, 250 (1920).

Prior to 1934 only tort claims evidenced by a judgment or settlement at the time a bankruptcy petition was filed were provable. In 1934, Section 633 of the Act was amended by adding clause (6) which made workmen's compensation awards provable. Act of June 7,1934 , ch. $424, \S 4 a(6), 48$ Stat. 911. Also. in 1934, negligence claims represented by a lawsuit filed and pending at the time of the filing of a petition vere made provable. Act of June 7, 1934, ch. 424, $\S 4 a(61 / 2), 48$ Stat. 911. Clause 61/2 was enacted to increase the value and effect of a discharge to a bankrupt natural person. Debtors and labor were powerful political forces in the United States in 1934. Then as now, however, there was no national association of tort victinis.

33. For example, there is no justification for negligent tort claims receiving more favorable treatment than willful tort claims. Yet, under Section 63a of the Bankruptcy Act, 11 U.S.C. \& 103a (1964), tort claims founded on negligence are more likely to be provable. Similarly, if a negligence victim is negotiating an out-of-court settlement and bankruptcy ensues, his claim is not provable unless he has a firm contract of settlement. But a victim who refuses to negotiate and files suit before bankruptcy has a provable claim. Again there is no adequate justification for favoring one class of tort victims.

34. If a tort claim is not provable, it is not dischargeable. Bankruptcy Act $\$ 17$. 11 U.S.C. § 35 (1964). As a result, the holder of such a claim may assert it against assets which a bankrupt natural person acquires after bankruptcy. In some situations the holder of a nonprovable claim may receive more compensation after bankruptcy than he would have if his claim had been provable.

35. See note 1 supra.

36. 11 U.S.C. \$ $215 \mathrm{~b}(5)$ (Section 77, Railroad Reorganization); 11 U.S.C. $\$ 500(1)$ (Chapter X, Corporate Reorganization); 11 U.S.C. \$ 707(2) (Chapter XI, Arrangements); 11 U.S.C. \$ 806(2) (Chapter XII, Real Property Arrangements); II U.S.C. § 1000(11) (Chup. ter XIII, Wage Eanners Plans) (1964). And tort claims not provable under present law 
alter the treatment of tort claims in straight bankruptcy so that all such claims against corporations are made provable in every type of proceeding authorized by the Bankruptcy Act. This alteration could be accomplished by adding a tenth clause to Section $63 \mathrm{a}$ of the Bankruptcy Act: ${ }^{37}$

[Debts of the bankrupt may be proved and allowed against his estate which are founded upon ....] (10) the right to recover from a bankrupt corporation actual damages caused by an act prior to the filing of the petition in bankruptcy for or against the corporation.

To avoid penalizing creditors for the "sins" of the corporation, the proposed amendment would make provable only actual, not punitive, damages. ${ }^{38}$ The amendment would in no way alter the general rule that a bankruptcy court has, within its sound discretion, the power to select the most appropriate method of liquidating any claim. ${ }^{\text {an }}$ Thus, a bankruptcy court may itself liquidate any tort claim or may decide to await the determination of another court of competent jurisdiction..$^{40}$

If it is thought unfair to allow the tort victim in a rare case to obtain partial compensation from the bankrupt corporation's insurer, employees, or stockholders and then to participate ratably with all the general creditors of the bankrupt until full compensation for the corporation's tort is obtained, Section 65 could be amended to prevent a tort claimant from getting ahead of general creditors because of partial compensation from outside sources. ${ }^{41}$

Since the proposed amendment to Section 63a makes more tort claims provable, the total number of claims provable against a bankrupt corporation's estate would naturally increase in many cases. As a result, other commercial creditors would receive a smaller share of the corporation's assets than they would under present law. However,

were provable in equity receiverships for corporations. Pennsylvania Stcel Co. v. New York City Ry., 161 F. 784 (S.D.N.Y. 1908).

37. 11 U.S.C. \& 103a (1964).

38. This result would be consistent with the general policy of the Act not to inflict upon the bankrupt's creditors penalties for the acts of the bankrupt. For cxample, Section $57 j$ of the Bankruptcy Act, 11 U.S.C. § 93j (1964), makes debts owed to the government as penalties non-allowable.

39. See 3 W. Collier, Bankruptcy If 57.15 (14th ed. 1961); cf. Ex parte Baldwin, 291 U.S. 610 (1934).

40. See generally 3 W. Collier, Bankruptcy If 57.15 (14th ed. 1961).

41. Cf. Bankruptcy Act $\S 65 d, 11$ U.S.C. $\$ 105 d$ (1964), which provides that creditors who have received dividends on their claims in foreign bankruptcy procecdings shall not participate in the distribution of a bankrupt's assets until all creditors of the same class have received an equal percentage dividend on their claims. If desirable, Section 65 could be amended by adding a section analogous to Subsection d to require similar treatment for those whose claims have been partially satisfied by the bankrupt's insurance. 
Tort Claims and the Bankrupt Corporation

commercial creditors could protect themselves from this possibility by insisting that a corporation maintain adequate tort liability insurance before credit is extended. ${ }^{42}$ Such an enforcement of insurance requirements by creditors would increase the probability that the tort victims of financially weak corporations would be compensated for their injuries.

42. In fact, it would be easier for commercial creditors to protect themselves by determining whether a corporation is adequately insured than it is for a creditor to determine the corporation's tax liabilities. Yet claims based on tax liability have a priority over unsecured commercial claims under Section 64 of the Act, 11 U.S.C. $\$ 104$ (1964), as amended, 11 U.S.C.A. \& 104 (Supp. 1968). 